\title{
Assessing geomorphosites used for rock climbing. The example of Monteleone Rocca Doria (Sardinia, Italy)
}

\section{Valeria Panizza, Marco Mennella, Sassari}

\section{Introduction}

Within the framework of national and international projects, a common methodology of assessment and classification of geosites has been developed over the past few years. It is a consequence, on the one hand, of the ever-increasing interest in the protection and appraisal of natural assets and, on the other, of the elaboration of the concept of «geomorphosite» (PANIzZA 2001). According to PANIZZa (2001), the concept calls for an integrative approach to research, taking both the dynamic processes of landforms and their relationship to cultural components into account (PAnIzZA \& Piacente 2003; Reynard 2004). Because of the link made between «scientific value» and «communal» or «cultural value», the results of such research are seen to give insight into geomorphological heritage, a characteristic which can also be understood as a resource to be managed (Panizza 2003; Pralong \& Reynard 2005). The exploitation of such a resource, however, calls for the awareness of the possible impacts of use on the resource itself (Panizza 1995). Further, if geomorphosites are seen as dynamic components of the environment, then attention should also be given to possible hazards that could put people moving within that specific environment at risk.

As is often the case with leisure sports activities, like mountain climbing, free climbing and rafting, the geomorphological resource is often the main motivation for destination choice. It is therefore advisable to not ignore the possible risks linked to the dynamic nature of the environment in which these activities take place (Panizza, V. 2005). In the case of outdoor activities, risk identification may focus on particular geological and geomorphological conditions, such as steep rock cliffs, high peaks, streams running through narrow canyons, and so on. However, there is seldom complete awareness of the real risks that such activities can sometimes involve due to the often superficial knowledge of the active processes to be found within the physical environment.

For many geographical areas, a coordinated management of sites with this particular form of tourist attraction may have many advantages, such as reduction of visitor pressure on traditional itineraries or sites (coastal areas, traditional trekking routes), or the reg- ulated and systematic control of current sites from the point of view of hazard risk and potential impact on the natural environment, or improvement of economic base of a site due to holistic management. Considering that in some areas, activities such as canyoning or free climbing attract thousands of tourists every year, the advantages may be substantial (LeONARD \& MAO 2003).

In the sector of free climbing, Sardinia, with its great geological and geomorphological diversity, offers more than 130 sites throughout its whole territory. The attractiveness of the area for climbers from all over Europe continues to grow, putting it on equal footing with other, longer established regions in Europe, such as South-Eastern France (Leonard \& Mao 2003). Climatic characteristics, geological complexity and the geomorphological setting have played a fundamental role in triggering the growth of this specialized form of tourism (LeONARD \& MAO 2003). However, the growth of this branch has not, as yet, been accompanied by a coordinated management project ensuring appropriate use of the sites in question.

In this paper, a method is presented to support the sustainable management of a climbing site that was recently opened near Sassari in North-Western Sardinia, Italy (Fig. 1). The climbing site lies on the tabular relief of the Su Monte ridge, near the village of Monteleone Rocca Doria. As is described in more detail below, both its «geomorphological» and «cultural value» are considered high (ARRU 1980; BARCA et al. 1992; Panizza \& Cannillo 1994; Sistu \& Tilocca 2003). With free climbing being offered along the calcareous ledge of the highest part of the ridge, the attractiveness of the site both for tourism and the economy in general, has increased significantly.

\section{Geographic setting}

The ridge on which the village of Monteleone Rocca Doria lies may be found in the heart of the LogudoroMejlogu volcanic district (Sistu \& Tilocca 2003). Most of the lithological features and relief landforms of the area's landscape are the result of volcanic events which affected the area during the Tertiary and Plio-Quaternary. Furthermore, there are close links between the geological and geomorphological features and the development of human settlements in this part of Sardinia, which boasts a rich diversity of archaeo- 


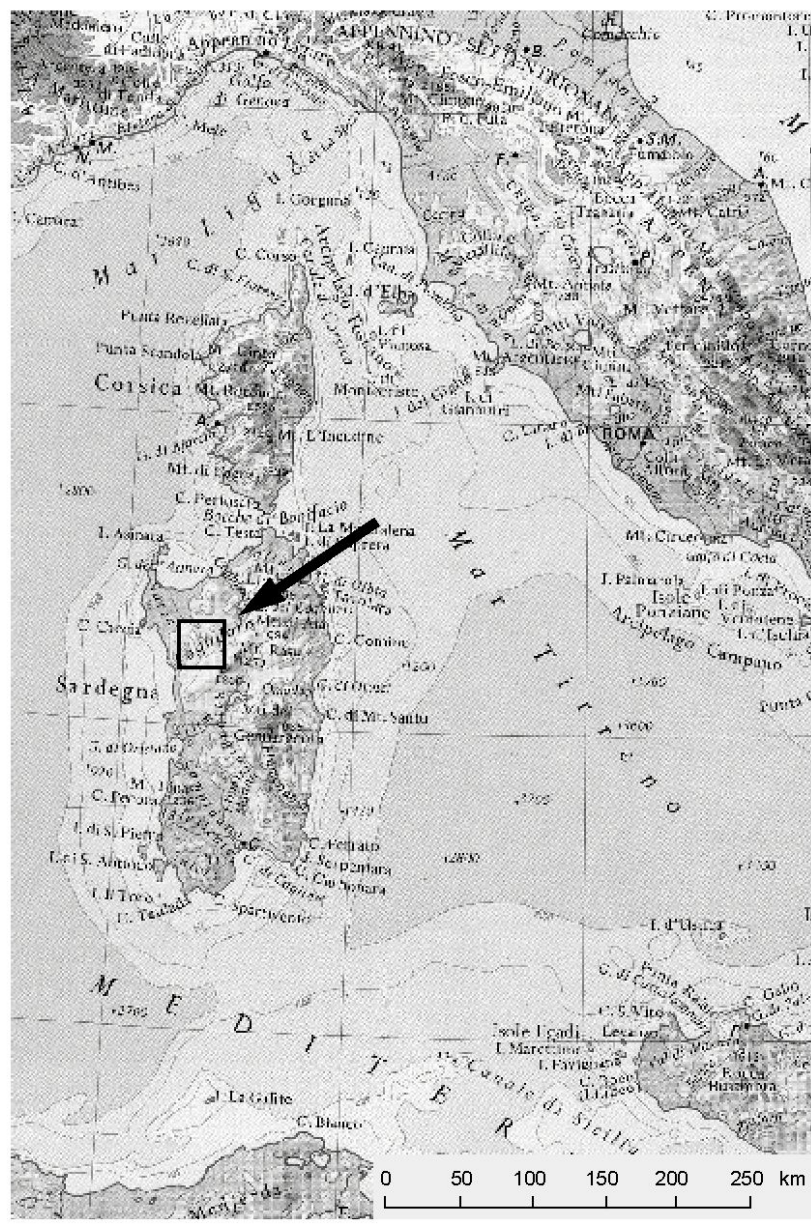

Fig. 1: Location of the study area Lage des untersuchten Gebietes Situation de la zone d'étude

Source: AtLANTE MONDIALE ZaNichelli 1997

logical artefacts. Several authors have identified the strong link between lithological features, the relief and archaeological sites with regards location, use of raw materials (volcanic rock) and exploitation of the existing morphology (Santoni 1992; Sistu \& Tilocca 2003). This correlation can also be found in the numerous monuments dating back to different epochs.

The River Temo, which flows across this area from north to south, has formed a wide meander around the northwestern side of the Su Monte ridge. Due to an artificial barrier constructed in the early 1980 s, a lake developed in this area. The Su Monte ridge has a tabular relief, slightly sloping to the south and bounded by vertical cliffs. Its highest elevation is $421 \mathrm{~m}$ a.s.l.; the village of Monteleone, which was built along the southern flank of the relief, lies at about $390 \mathrm{~m}$ a.s.l. (Fig. 2).
The Tertiary volcanism of this region is characterised by the eruption of mainly andesitic lavas, intercalated with rhyodacites of ignimbritic origin. Many of these extrusive rocks - as in the case of Su Monte - are overlain by marine calcareous deposits from the MidUpper Miocene. The Oligo-Miocene volcanism of Sardinia is related to the opening of the western Mediterranean, in particular to the Algerian-Provencal basin and the northern Tyrrhenian. From the Burdigalian onwards, basins hosting marine sediments associated with semi-graben structures were active in an extensional regime (FunedDA et al. 2000). The Monteleone Rocca Doria area is essentially a volcanic sequence formed by pyroclastic flow deposits and andesitic lavas. In the study area, the marine facies, made up mainly of marls and calcarenites, crop out subordinately to the volcanic sequence, which it overlies non-conformably (CARMIGNan et al. 2001). The tabular ridge of $\mathrm{Su}$ Monte (Photo 1) shows ignimbritic rocks of the OligoMiocene extrusive series at the bottom, covered on the top by Miocene calcarenites and biocalcarenites. High vertical cliffs have developed in this upper series. Both series have a sub-horizontal attitude.

The geological constitution and tectonic evolution of the area have considerably conditioned the relief forms. The extrusive bodies sometimes show a domelike shape whereas elsewhere they result from collapse morphologies alternating with tabular slabs which characterise the flows of the Tertiary extrusive series and the overlying Miocene sedimentary deposits. Moreover, there are numerous examples of steplike morphologies (cuestas), both in the extrusive series and at the stratigraphic boundary to the carbonate sedimentary deposits. At present, the modelling of the Su Monte ridge takes place mainly along the steep calcareous edges, where the effects of karst erosion are combined with those resulting from rill wash along the rocky faces and at the top of the relief.

\section{3 «Scientific» and «historical-cultural value»}

On this isolated ridge encircled by a meander of the River Temo, human settlements have been established throughout history, exploiting the natural defensive position offered by its particular structure. The Dorias (a Genoese family of the Ghibellin faction) occupied this region in 1237 and built a castle (now in ruins) in what used to be the hamlet of Monteleone. This site, though, had already been inhabited many centuries before: Carthaginian and Roman coins and the remnants of numerous Roman cisterns bare witness to these earlier settlements (ARru 1980). Apart from the natural defensive position of the ridge, the presence of several springs at the boundary between the calcarenites and the underlying ignimbrites may have favoured 


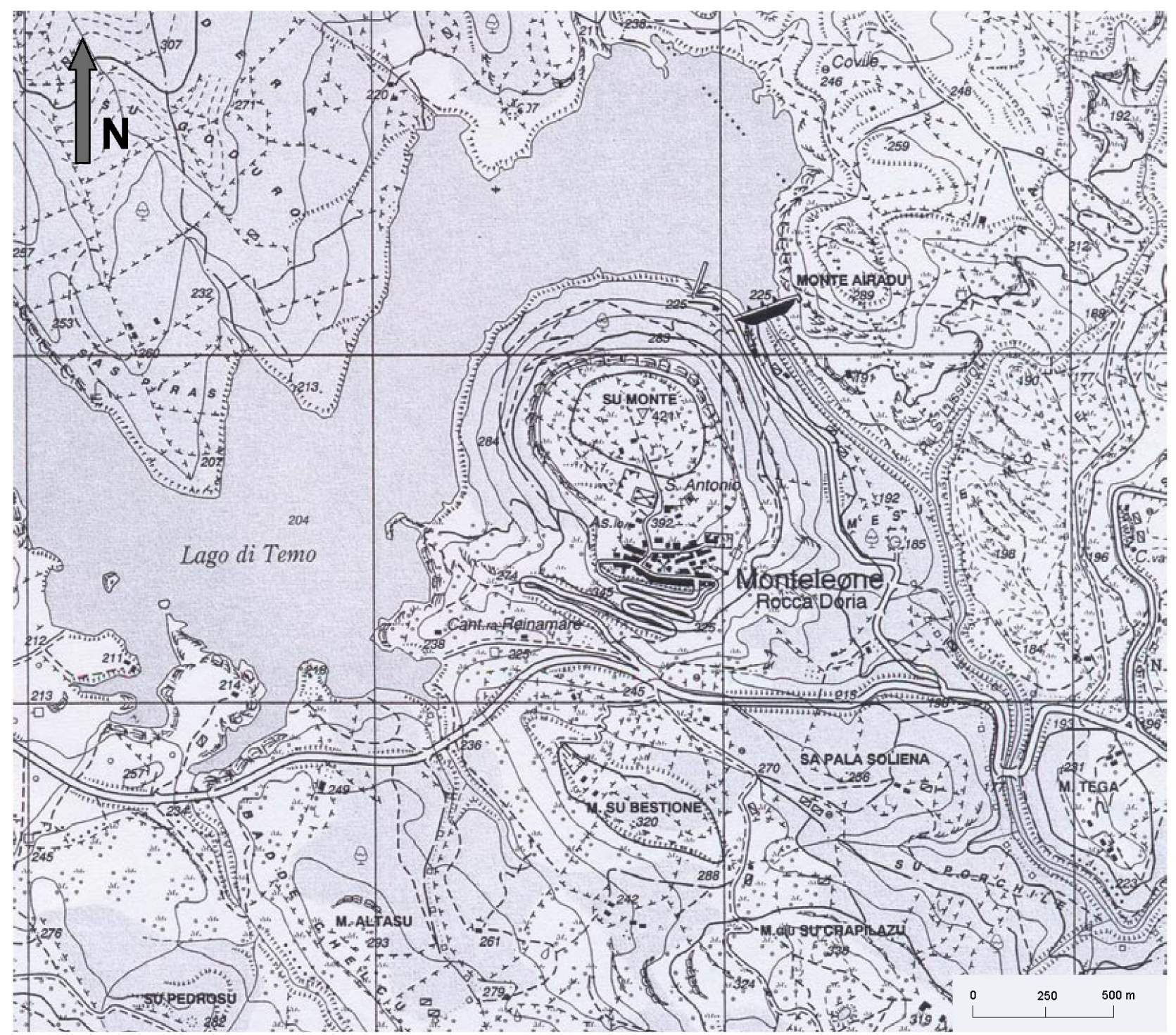

Fig. 2: Monteleone Rocca Doria

Monteleone Roccca Doria

Monteleone Rocca Doria

Source: Topographic map of Italy, after IGM Sheet «Mara», no. 479

human settlements in even earlier times, such as the Nuraghi civilisation. Besides the ruins of the Doria stronghold and the beautiful medieval churches built during their reign, there are many other sites of interest reflecting the rich historical-archaeological heritage of the area (Terrosu Asole 1980; Brigaglia 1995).

The whole area has also been studied by the scientific community within the framework of development and conservation projects due to the national importance of Sardinia in the Tertiary geodynamic (FEDERICI 1985; PanizZa \& CANNILlo 1994; Sias 1995; SisTu \&
TILOCCA 2003). The many extrusive bodies, some of which are textbook examples from a morphological and evolutive point of view (Photo 1), and the tabular reliefs, witnesses of the lava episodes and the marine and continental sedimentary phases, allow reconstruction of the geological events that occurred in Sardinia during the Cenozoic. The geomorphological processes formed step-like slopes, deep and narrow valleys, relief inversion morphologies and cavities created by chemical erosion on calcareous and igneous lithologies, the biggest of which are often used by shepherds as shelter for their sheep. 


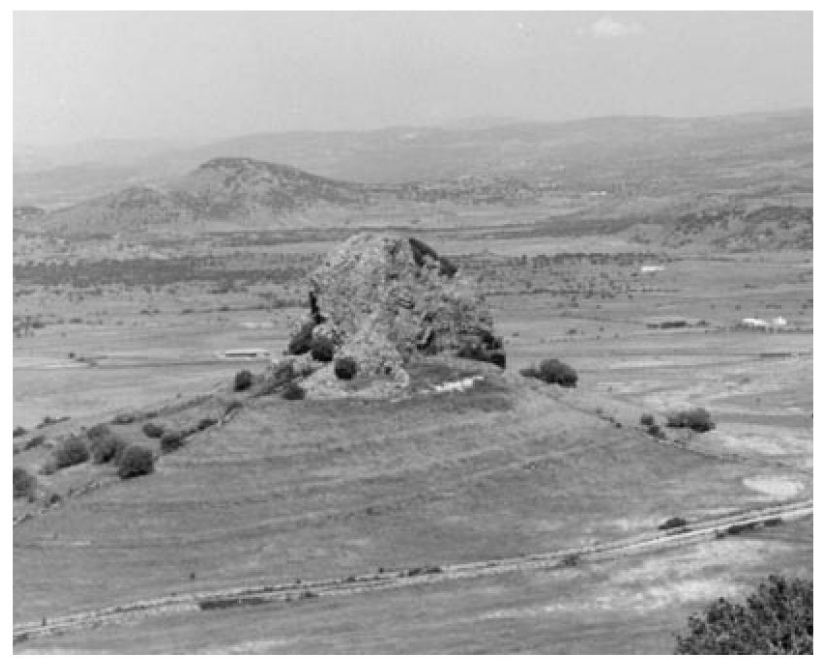

Photo 1: The neck of Pedra Mendarza, linked to PlioQuaternary volcanism, in the surroundings of Monteleone Rocca Doria

Die Spitze des aus einer vulkanischen Phase im PlioQuartär stammenden Pedra Mendarza, in der Umgebung von Monteleone Rocca Doria

Le neck de Pedra Mendarza, lié à une phase de volcanisme plio-quaternaire, dans les environs de Monteleone Rocca Doria

Photo: V. PANIzZa

\section{Aims of the study}

Due to the high «scientific» and «cultural value» of the whole region, a heterogeneous mixture of tourists and visitors are attracted to the region every year. An assessment plan allowing co-ordinated asset management has not yet been developed for the area. Like in most Sardinian inland areas, the population density of the region is very low, especially if compared to other Italian rural areas, although many tourist activities are offered here thanks to the exceptional landscape. The numerous tabular ridges found all over the area offer ideal conditions for free climbing, and the vertical rock faces of the Monteleone Rocca Doria ridge has been recently equipped for this activity with over 40 routes ranging from $15 \mathrm{~m}$ to $35 \mathrm{~m}$ in height.

The aim of the geomorphological assessment presented here was to investigate possible risks and impacts that could occur on the site due to increased human frequentation. Indeed, the opening of the climbing routes was not preceded by any assessment of the stability of the slopes, an aspect that may be considered necessary if the geological-technical characteristics of the calcareous rock outcropping and episodes of instability registered in analogue slopes over time are taken into account. In this paper, a method is presented to support the sustainable management of the climbing site by proposing options for utilisation that are sensitive to both the needs of the climbers and the environment in which the site is embedded.

\section{Methodology}

The methodology designed for assessment of the suitability of an area for free climbing (MоттA, PAnizzA \& PECCI) involves two steps. In a first step, a general assessment of the value and the quality of the site is implemented. This involves identification of the geomorphologically active processes on the rock walls opened for free climbing and a rating of their geological-technical parameters. The aim is evaluation of possible risk factors for the climbers.

In a second step, possible impacts on the geomorphological resource as a consequence of use are identified. This is particularly relevant where stress of use could move a system from marginal stability to instability. Attention is paid here specifically to external forces linked to human presence and related to the dynamic processes present on site (PANIZZA, M. 2005).

\subsection{Assessment of hazard factors on the rock walls}

For the assessment of potential hazard factors, the methodology proposed by MoтTA et al. for similar contexts and situations was adapted for the specific needs of the site. Field data was collected and interpreted in two phases. In the first phase, an initial set of data and information was collected on a record card, foreseen for this purpose, in order to define the geomorphological characteristics of the study area. In particular, the morphometric features of the rock faces, such as inclination, height and elevation, were surveyed. In a next step, the morphological and structural factors, as indicators of possible instability, were identified and classified according to their degree of activity. Thus, aspects such as degradational scarp edge, detachment surfaces, freshness of debris at the foot of the slopes were noted. Each of the active hazard factors identified was recorded and described in detail on an appropriate card (Tab. 1). Here, geomorphological hazard and other characteristics such as meteo-climatic data, the state of paths and other human factors which may increase risk in certain situations were taken into account.

The second assessment phase focused on the definition of the geological-technical parameters of the Monteleone Rocca Doria rock face. A semi-quantitative approach suggested by Amanti \& Pecci (1995) and modified by МоттA et al. was selected for this phase. The data collected here was also recorded on 


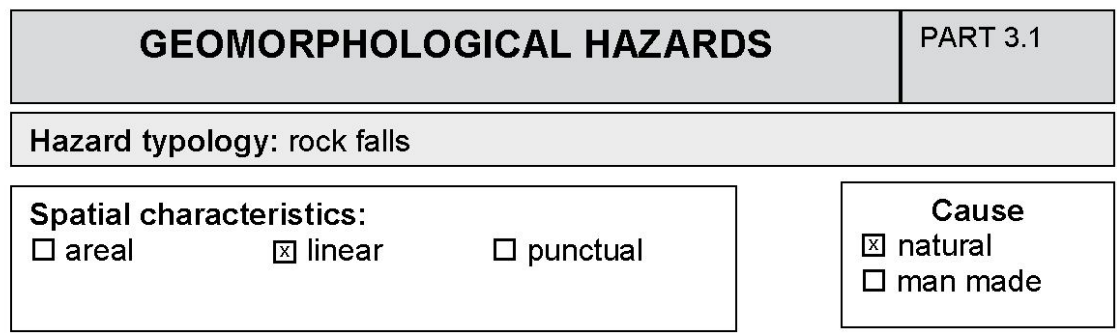

Specific description of the hazards:

Main preparing causes: dormant edge of monocline relief and presence of wide joints. Chemical and mechanic erosion induced by presence of water in the discontinuities.

Main triggering causes: Progressive widening of the discontinuities and related gravity falls of blocks and boulders. Direct stress.

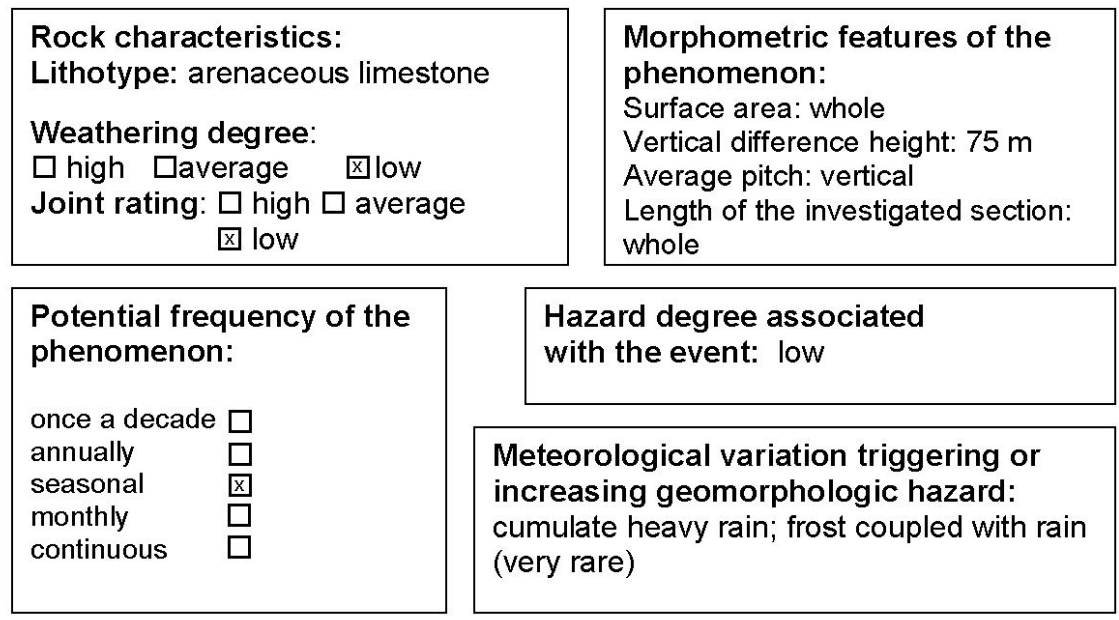

Tab. 1: Form used for the description of the geomorphological hazards

Formular zur Beschreibung der geomorphologischen Gefahren

Formulaire utilisé pour la description des aléas géomorphologiques

a card (Tab. 2 and 3). For each parameter, the increasing hazard rates are indicated in relation to the specific patterns of behaviour of the actual rock mass, according to the variation of «parameter values». Qualitative parameters allow the assessment of the degree of cementation, weathering and the characteristics of discontinuities, bedding and permeability. Quantitative data permit classification of the rock mass. For the latter purpose, Rock Mass Rating (RMR) as forwarded by BIENIAWSKI (1979) and modified by AMANTI et al. (1994) was chosen. For the RMR, six values are collected, each representing a specific characteristic of the rock mass. The attitude of the slope and discontinuity surfaces were measured using a geological compass. As the portion of the rock wall examined showed two main systems of discontinuity along the $\mathrm{N} 200^{\circ}$ and $\mathrm{N} 290^{\circ}$ planes, corresponding to a large, isolated rock wedge, measurements were carried out on both planes.

The final RMR is the sum of all rock characteristics values (RMR = R1+R2+R3+R4+R5+R6) (Tab. 2 and $3)$. Each of these parameters represents a specific characteristic of the rock mass and was calculated directly from the data presented in Tabs. 2 and 3.

The final RMR value allows the rock mass to be classified according to the five classes proposed by BIENIAWSKI (1979). Depending on the final RMR, a rock face can be classed according to rock typology, ranging from Class 1 (90-100, very good rock) to Class 5 ( $<25$, very poor rock) (BIENIAWsKI 1979). The values for the Monteleone Rocca Doria rock face are presented in Tabs. 2 and 3. 


\begin{tabular}{|c|c|c|c|c|c|}
\hline \multirow{2}{*}{\multicolumn{2}{|c|}{$\begin{array}{l}\text { TABLE } 2 \\
\text { ORIENTATION OF THE ROCK WALL }\end{array}$}} & 1 & 2 & 3 & 4 \\
\hline & & \multicolumn{2}{|l|}{ Strike N 290 } & \multicolumn{2}{|l|}{ Dip: vertical $\left(\mathbf{8 5}^{\circ}-\mathbf{9 0}^{\circ}\right)$} \\
\hline I a & NATURE OF WEATHERING & Absent & Sand/granular & Silt & Clayey \\
\hline I b & DEGREE OF WEATHERING & $\begin{array}{l}\text { Unweathered or } \\
\text { slightly weathered }\end{array}$ & $\begin{array}{l}\text { Poor - very } \\
\text { weathered }\end{array}$ & Completely weathered & Soil \\
\hline II & $\begin{array}{c}\text { DEPTH/THICKNESS OF } \\
\text { WEATHERING }\end{array}$ & $<1 \mathrm{~m}$ & $1-3 \mathrm{~m}$ & $3-5 m$ & $>5 \mathrm{~m}$ \\
\hline $\begin{array}{c}\text { III } \\
\text { (R3) }\end{array}$ & $\begin{array}{c}\text { HARDNESS } \\
\text { (DISCONTINUITIES SPACING) }\end{array}$ & $>100 \mathrm{~cm}$ & $30-100 \mathrm{~cm}$ & $5-30 \mathrm{~cm}$ & $<5 \mathrm{~cm}$ \\
\hline IV a & $\begin{array}{l}\text { PERSISTANCE OF } \\
\text { DISCONTINUITIES }\end{array}$ & $\begin{array}{c}\text { Yes, on sight } \\
\text { Yes, on piton test } \\
\text { (persistent) }\end{array}$ & $\begin{array}{l}\text { Yes, on sight } \\
\text { No, on piton test } \\
\text { (semi-blind) }\end{array}$ & $\begin{array}{l}\text { No, on sight } \\
\text { Yes, on piton test } \\
\text { (semi-persistent) }\end{array}$ & $\begin{array}{l}\text { No, on sight } \\
\text { No, on piton test } \\
\text { (blind) }\end{array}$ \\
\hline $\begin{array}{l}\text { IV b } \\
(\mathrm{R} 4)\end{array}$ & $\begin{array}{c}\text { ATTITUDE OF } \\
\text { DISCONTINUITIES }\end{array}$ & $\begin{array}{c}\text { Yes } \\
\text { (see table 3) }\end{array}$ & No & & \\
\hline $\begin{array}{l}\text { IV c } \\
\text { (R2) }\end{array}$ & $\begin{array}{l}\text { TOTAL NUMBER OF JOINTS } \\
\text { PER } \mathbf{m}^{2}\end{array}$ & 20 & & & \\
\hline $\mathrm{V}$ & $\begin{array}{c}\text { STRENGTHENING LAYER ON } \\
\text { WEAK LAYERS }\end{array}$ & Yes & No & & \\
\hline VI & $\begin{array}{c}\text { PERMEABLE LAYERS ON } \\
\text { NON-PERMEABLE }\end{array}$ & Yes & No & & \\
\hline VII & $\begin{array}{c}\text { NATURAL FRICTION ANGLE } \\
\text { ( } \Phi \text { RES) }\end{array}$ & $>\mathbf{2 5 ^ { \circ }}$ & $20^{\circ}-25^{\circ}$ & $15^{\circ}-20^{\circ}$ & $<15^{\circ}$ \\
\hline VIII & $\begin{array}{c}\text { GEO-TECHNICAL } \\
\text { COMPLEXITY }\end{array}$ & Non-complex & Shale & Alternances with clay & $\begin{array}{c}\text { Chaotic with clayey } \\
\text { matrix }\end{array}$ \\
\hline $\begin{array}{c}\mathrm{Ixb} \\
\text { (R1) }\end{array}$ & $\begin{array}{c}\text { CHARACTERISTIC OF } \\
\text { COMPRESSION STRENGTH }\end{array}$ & Number of geologist & lammer hits (Rock): & 3 & \\
\hline $\mathrm{X}$ & DEFORMABILITY & $\begin{array}{l}\text { Layered and } \\
\text { massive rock }\end{array}$ & $\begin{array}{l}\text { Shale and } \\
\text { alternances }\end{array}$ & $\begin{array}{c}\text { Granular and compact } \\
\text { or overconsolidated } \\
\text { and cohesive hearth }\end{array}$ & $\begin{array}{c}\text { Granular and cohesive } \\
\text { disturbed hearth }\end{array}$ \\
\hline $\mathrm{XI}$ & $\begin{array}{c}\text { PROGRESSIVE BREAKING } \\
\text { HAZARD }\end{array}$ & $\begin{array}{l}\text { Overconsolidated } \\
\text { clay and } \\
\text { unweathered rock }\end{array}$ & $\begin{array}{l}\text { Overconsolidated } \\
\text { clay, weathered } \\
\text { and poorly } \\
\text { cemented rock }\end{array}$ & $\begin{array}{l}\text { Poorly cemented and } \\
\text { weathered rock }\end{array}$ & $\begin{array}{c}\text { Overconsolidated, } \\
\text { weathered and weak } \\
\text { clay }\end{array}$ \\
\hline $\begin{array}{c}\mathrm{XII} \\
(\mathrm{R} 6)\end{array}$ & PERMEABILITY & Very permeable & $\begin{array}{c}\text { Permeable on } \\
\text { average }\end{array}$ & Poorly permeable & Non-permeable \\
\hline XIII & $\begin{array}{c}\text { DEGREE OF COHESION OR } \\
\text { CEMENTATION }\end{array}$ & Cemented & Overconsolidated & $\begin{array}{c}\text { Normally } \\
\text { consolidated }\end{array}$ & Underconsolidated \\
\hline XIV & $\begin{array}{c}\text { PRESENCE OF WEAKNESS } \\
\text { ZONES }\end{array}$ & $\begin{array}{l}\text { Very few failure } \\
\text { surfaces without } \\
\text { clay }\end{array}$ & $\begin{array}{c}\text { Few failure } \\
\text { surfaces also with } \\
\text { clay }\end{array}$ & $\begin{array}{c}\text { Several failure } \\
\text { surfaces }\end{array}$ & $\begin{array}{c}\text { Abundant failure } \\
\text { surfaces }\end{array}$ \\
\hline
\end{tabular}

Tab. 2: Form used for the semi-quantitative assessment of geo-technical features of the rock mass and of the rock wall Formular zur semi-quantitativen Evaluation von geotechnischen Charakteristika des Felsens und der Felswand Formulaire pour l'évaluation semi-quantitative des caractéristiques géotechniques du rocher et de la paroi

The uniaxial compressive strength (R1 in Tab. 2 and 3) was also be assessed by means of the Schmidt hammer, which assesses the rock hardness by means of its rebound value $\langle\mathrm{R} »$. Rebound is related to the material's bulk density and provides the uniaxial compressive strength expressed in MPa.

\subsection{Impact assessment}

As argued in the first part of the paper, the use of an active landform, as for example a rock slope, should be accompanied by a suitable risk assessment related to the geomorphologically active processes. Similarly, the targeted geomorphological resource object may be influenced by the human activities and if these alterations are not reversible, this could compromise not only the quality of the site but also its subsequent use (Panizza 2003; Pralong \& Reynard 2005). Thus, it is necessary to assess both the potential risks and impacts of use. Free climbing is not generally associated with strong impacts on the natural surrounding but such activities can induce alterations on the rock walls in cases of marginal rock face stability (PANIZZA, M. 2005). Possible triggers of alterations may be the direct stress caused by climbers hanging on rock portions which may lead to blocks of various sizes being removed and rolling down the slope, or damage caused 


\begin{tabular}{|c|c|c|c|c|c|c|c|c|}
\hline \multicolumn{7}{|l|}{ TABLE 3} & \multicolumn{2}{|c|}{$\begin{array}{c}\text { IXa FRICTIONAL } \\
\text { CHARACTERISTIC OF } \\
\text { STRENGTH }\end{array}$} \\
\hline (R5) & \multicolumn{2}{|c|}{$\begin{array}{l}\text { Attitude (dip } \\
\text { direction) }\end{array}$} & $\begin{array}{c}\text { Opening } \\
(\mathrm{mm})\end{array}$ & Filling & $\begin{array}{c}\text { Persistence } \\
\text { (yes/no) }\end{array}$ & Percolation & $\begin{array}{r}\text { Average } \\
\text { spacing }\end{array}$ & $\begin{array}{c}\text { Barton } \\
\text { profile }\end{array}$ \\
\hline $\begin{array}{l}\text { STRATIFICATION } \\
\text { OR } \\
\text { SCHISTOSITY } \\
\end{array}$ & $\underset{290^{\circ}}{\mathrm{N}}$ & $20^{\circ}$ & 200 & 0 & Yes & No & $5-60 \mathrm{~cm}$ & $\begin{array}{c}\text { High } \\
\text { roughness } \\
\text { (class 10) }\end{array}$ \\
\hline \multicolumn{9}{|l|}{ FAULT } \\
\hline $\begin{array}{l}\text { JOINT FAMI Y } \\
1\end{array}$ & $\begin{array}{c}\mathbf{N} \\
200^{\circ}\end{array}$ & Vertical & $10-50$ & No & Yes & No & $1000 \mathrm{~cm}$ & $\begin{array}{c}\text { High } \\
\text { roughness }\end{array}$ \\
\hline $\begin{array}{l}\text { JOINT FAMI Y } \\
2\end{array}$ & $\stackrel{\mathrm{N}}{290^{\circ}}$ & Vertical & $10-50$ & No & Yes & No & - & $\begin{array}{c}\text { High } \\
\text { roughness }\end{array}$ \\
\hline $\begin{array}{l}\text { JOINT FAMLY } \\
3\end{array}$ & & & & & & & & \\
\hline
\end{tabular}

\begin{tabular}{|l|l|}
\hline $\begin{array}{l}\text { SCHMDT HAMMER } \\
\text { (rocks) }\end{array}$ & $\begin{array}{l}\text { Joint family 1: Schmidt rebound number on average 16,7, corresponding to about 20 } \\
\text { MPa (Sample total 9) } \\
\text { Joint family 2: Schmidt rebound number an average 18,5, corresponding to about 20 } \\
\text { MPa (Sample total 8) }\end{array}$ \\
\hline $\begin{array}{l}\text { BARTON PROFIE - TO } \\
\text { BE DRAWN (rocks) }\end{array}$ & $\begin{array}{l}\text { Profile No. 10, corresponding to 18-29 intervals of JRC (Joint Roughness } \\
\text { Coefficient) values }\end{array}$ \\
\hline
\end{tabular}

Tab. 3: Form for the evaluation of discontinuities of the rock mass

Formular zur Evaluation von Fels-Unregelmässigkeiten

Formulaire pour l'évaluation des discontinuités de la roche

by movement of climbers on access paths, especially if the paths are steep and close to the edges.

In Monteleone,impacts related only to the presence of the climbers were assessed as this activity is currently the main reason why tourists are attracted to the area. Assessment occurred by direct observation. Over a period of several months, the number of climbers on the rock face at weekends and their movements within the site were noted.

\section{Results}

\subsection{Results of the hazard assessment}

From the viewpoint of geomorphological processes, the Su Monte calcareous edge is affected by various discontinuity families which, combined with the bed- ding planes, isolated rock wedges, blocks and pillars, karst activity on the rock's carbonate component and the mechanical removal of terrigenous elements and residual minerals by running and infiltration waters, cause progressive widening of the joints. This favours the detachment of debris and blocks. At the bottom of the cliffs and along the vegetation-covered slopes, there are numerous blocks of various sizes, some of them rather large, resulting from rock falls. Some of the blocks' characteristics, such as weathering and various stages of lichen colonisation, indicate recent detachment. Furthermore, from the top of the ridge it is possible to observe large-sized blocks which have rolled down as far as the artificial impoundment, covering a difference of altitude exceeding $150 \mathrm{~m}$.

With reference to the geological-technical data, the values calculated for the rock face gave a final RMR 
of 56. This corresponds to Class 3 of the classification types forwarded by BienIAwski (1979). In other words, the site demonstrates «average to fair rock». Thus, the RMR values indicate a fair mechanical strength of the rock in general. This is in contrast to the values obtained by means of the Schmidt hammer, which were rather low (Tab. 1 and 2). The discrepancy of values may be ascribed to the fact that the Schmidt hammer measurements were carried out on rock face discontinuities that were not only considerably weathered but also bounded by potentially unstable rock wedges. Indeed, we athering along discontinuity joints can drastically reduce the rock's mechanical characteristics with respect to those portions affected by a lesser degree of weathering. On the rock face investigated, the lowest stability conditions were found along rock wedges bounded by the discontinuity planes $\mathrm{N} 200^{\circ}$ and $\mathrm{N} 290^{\circ}$. These sections were not connected to the slope by a rock bridge at the bottom (Photo 2).

\subsection{Results of the impact assessment}

The results of the direct observation of climbers indicate that during the period of investigation, numbers ranged from 4-8 persons per weekend to a maximum of 50 persons. The activities of this particular group of tourists were limited to the rock faces themselves, the area below the rock faces and the access path. As the access path is marked and does not present instability conditions, the only negative impact that could be discerned was possible intensification of processes of degradation already identified in the risk assessment. However, considering the number of climbers that visited the site during the investigation, this does not appear to have a significant impact at present.

Thus, the conclusions that can be drawn from this two-phased assessment is that the Monteleone cliffs equipped for free climbing show a good rock quality from a geomechanical point of view. Although they have a high percentage of terrigenous fractions, these calcarenites are sound and only slightly weathered. In addition, although they are affected by discontinuity planes, their number is limited. Therefore, the strength and continuity of the geological-technical parameters of these rocks are only slightly affected by the presence of joints. The main hazard factors identified are linked to the reduction of rock strength in correspondence with large rock portions only where (a) the latter are completely isolated by discontinuities all along their perimeter; (b) they show either vertical or overhanging faces and (c) have no support at the bottom. Meteoric degradation tends to make the joints wider and deeper, especially by means of karst solution processes. Moreover, on the basis of direct observations, the frequency of rock and debris fall is mainly

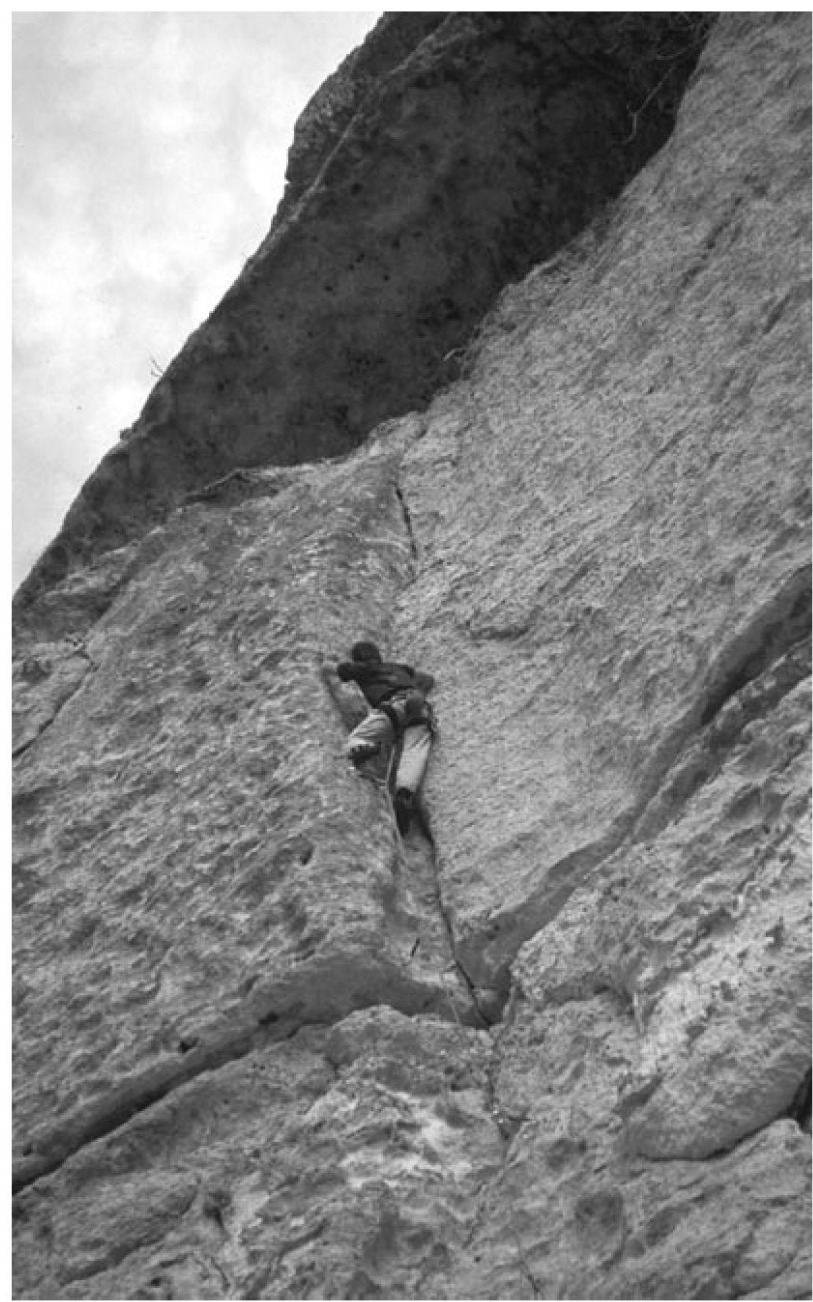

Photo 2: Climber on the investigated rock wall Kletterer in der untersuchten Felswand Grimpeur sur la paroi d'escalade étudiée Photo: V. Panizza

seasonal, in concomitance with intense and prolonged precipitation. It is possible that debris fall events may also occur following the movements of free climbers on the most weathered rock portions.

\section{Recommendations for sustainable management}

As the recent opening of the climbing sector has led to a general increase in tourism, it appears that the promotion of the general geomorphological value of the site, and thus a greater awareness of its «scientific» and «cultural value», should be targeted at the specific groups drawn to the region, such as the climbers. It is expected that this form of information channelling will lead to greater interest in the whole area in general 
and to greater respect in the use of the site. Thus, it is recommended that the following steps be taken:

- creation of informative and target-sensitive documents in which data on the climbing routes, a brief geological overview of the area and geomorphological information can be combined,

- installation of an information board summarising and explaining possible risks related to identified geomorphological hazard factors,

- information about correct behaviour for personal safety and for the sake of the natural environment,

- proposals for alternative routes of scientific-cultural interest that can be linked to climbing itineraries in the Monteleone area.

\section{Conclusion}

Within a few months of the opening for free climbing of the high calcareous slopes which make up the upper part of Monteleone Rocca Doria relief, a strong increase in number of climbers and a general increase of visitors to the site was registered. As a consequence, scientific, historical, cultural and socioeconomical interest in the area intensified. Considering the particular geological and geomorphological evolution of the region and its rich cultural heritage, the site is assumed to have a particularly high «geomorphositic value», according to the definition proposed by Panizza \& Piacente (2003). As such, it was considered potentially interesting for further tourism promotion coupled with increased nature conservation. However, as the increased movement of tourists appeared to be linked directly to the recent opening of the climbing sector, the paper presents a specific approach to geomorphosite assessment focusing on promotion of correct management of the site by means of risk analysis and impact assessment. This methodology has already been tested in other free climbing sites (MotTA et al.) for the «general» assessment of a natural rock wall. Regarding geomorphologic hazard and rock wall stability, localized problems of instability could be detected. These were mainly related to large isolated rock portions weathered by karst processes or to the falling of single blocks stressed by the movement of the climbers. Concerning the impact on the site, the climbing activity does not seem to cause significant stress on the environment. It also does not appear to be related to any other strong action triggering instability. The results of the assessment are to be shared with the climbing community in view of a better management of the safety and environmental conditions of the rock walls. Further, based on the results of the assessment, suggestions are made for improved exploitation of the site in order to stimulate sustainable tourism in areas not usually targeted by mainstream tourism.

\section{References}

Amanti, M. \& M. Pecci (1995): Proposta di una scheda per la raccolta e l'informatizzazione dei dati geologico-tecnici utili alla caratterizzazione e classificazione degli ammassi rocciosi. - In: Quaderni di geologia applicata $1: 1-8$

Amanti, M., Pecci, M., Scarascia Mugnozza, G. \& R. VALLESI (1994): Comparison and critical review of quick field data collection methods on rock slope: a contribution from climbing techniques and experiences. - In: Proceedings of the Convegno Internazionale per la Protezione e lo Sviluppo dell'Ambiente Montano «Man and Mountain '94», 20-24 giugno, Ponte di Legno, Brescia: 189-198.

ARru, D. (1980): Monteleone Roccadoria. - Sassari: Edizioni Libreria Dessì.

Barca, S., Di Gregorio, F. \& C. CAnNillo (1992): Rilevamento e valutazione dei monumenti geologici e geomorfologici del Meilogu-Logudoro (Sardegna NW). - In: Bollettino dell'AIC 86: 71-84.

BienIAwski, Z.T. (1979): Geomechanic classification of rock masses and its application in tunnelling. - Proceedings of the $4^{\text {th }}$ Congress on Rock Mechanics, A: 27-32.

Brigaglia, M. (1995): Storia della Sardegna. - Villanova Monteleone (SS): Soter Editrice.

Carmignani, L., Oggiano, G., Barca, S., Conti, P., Salvadori, I., Eltrudis, A., Funedda, A. \& S. Pasci (2001) Geologia della Sardegna. Note illustrative della Carta Geologica della Sardegna a scala 1:200.000. - In: Memorie descrittive della carta geologica d'Italia 60, Roma: 1-283.

FedericI, P.R. (1985): Suggestivi segni di una remota attività vulcanica. - In: Asole, A. (dir.): Sardegna. L'uomo e le montagne. - Milano: A. Pizzi: 105-115.

Funedda, A., Oggiano, G. \& S. Pasci (2000): The Logudoro Basin. A key area for the tertiary tectonosedimentary evolution of North Sardinia. - In: Bollettino della Società Geologica Italiana 119: 31-38.

LeONARD, M. \& P. Mao (2003): La géomorphologie comme facteur de localisation et d'attractivité des sites de pratiques sportives de pleine nature en France. - In: Géomorphologie et tourisme. Actes de la Réunion annuelle de la Société Suisse de Géomorphologie, Finhaut, 21-23 septembre 2001, Lausanne: Travaux et recherches 24: 79-91.

Motta, M., Panizza, V. \& M. Pecci: Geomorphologic risk assessment on natural rock wall for free climbing practice. - In: Geografia fisica e dinamica quaternaria Special issue (in press).

Panizza, M. (1995): Geomorfologia. - Bologna: Pitagora.

Panizza, M. (2001): Geomorphosites: concepts, methods and examples of geomorphological survey. - In Chinese science bulletin 46, Supp. vol.: 4-6.

Panizza, M. (2003): Géomorphologie et tourisme dans un paysage culturel intégré. - In: Géomorphologie et 
tourisme. Actes de la Réunion annuelle de la Société Suisse de Géomorphologie, Finhaut, 21-23 septembre 2001, Lausanne: Travaux et recherches 24:11-18.

Panizza, M. (2005): Manuale di geomorfologia applicata. - Milano: Franco Angeli.

Panizza, M. \& S. Piacente (2003): Geomorfologia culturale. - Bologna: Patron.

PAnizza, V. (2005): Rischio geomorfologico e turismo. - In: Panizza, M. (ed.): Manuale di geomorfologia applicata, cap. 12. - Milano: Franco Angeli: 302-316. Panizza, V. \& C. CAnnillo (1994): Rilevamento e valutazione di beni geografico-fisici di tipo geologico e geomorfologico in un'area della Sardegna nord-occidentale. - In: Rivista geografica italiana 101: 545-576. Pralong, J.P. \& E. ReYnard (2005): A proposal for a classification of geomorphological sites depending on their tourist value. - In: Il Quaternario 18, 1, volume speciale: $315-321$.

ReYnaRD, E. (2004): Géotopes, géo(morpho)sites et paysages géomorphologiques. - In: REYNARD, E. \& J.P. Pralong (eds): Paysages géomorphologiques. - Lausanne:Travaux et recherches 27:123-136.

SANTONI, G. (1992): La distribuzione dei nuraghi in rapporto alle caratteristiche geo-litologiche. - In: Collezione Archivio Storico Sardo di Sassari 10.

SIAS, S. (1995): Vulcanismo del Logudoro-Mejlogu (Sardegna settentrionale): un'area per un parco diverso. - In: IV Convegno Internazionale di Studi: La Sardegna nel mondo mediterraneo, vol. 8. - Bologna: Patron: 97-105.

Sistu, G. \& G. Tilocca (2003): Itinerari nel vulcanismo del Logudoro. - Cagliari: Cooperativa Universitaria Editrice Cagliaritana (CUEC).

Terrosu Asole, A. (1980): Linsediamento umano medievale e i centri abbandonati tra il secolo XIV e il secolo XVII. - Supplemento al fascicolo II dell'Atlante della Sardegna. - Roma: Edizioni Kappa.

\section{Abstract: Assessing geomorphosites used for rock climbing. The example of Monteleone Rocea Doria (Sardinia, Italy)}

Within the framework of geomorphosite assessment with reference to tourism potential, a new field of research has opened up focusing on sites used for outdoor activities, like free climbing. This line of research in particular focuses on the suitability of geological and geomorphological characteristics of a specific site for a particular sport. Concentrating on geomorphological hazard, rock quality, tourism capacity and site vulnerability, a method of assessment was designed and tested on a number of important Italian climbing sites. Using the results of the Monteleone Rocca Doria (Sardinia, Italy), the article presents the proposed approach of assessment. Although the site in question is recognised for its «scientific», «aesthetic» and «cultural value», it has drawn attention for its attractiveness for rock climbers in particular. Thus, the aim of the assessment was to support management of the site by proposing options for utilisation that are sensitive to both the needs of the climbers and the environment in which the site is embedded. In particular, attention was given to potential geomorphologically-related risks for climbers, the impacts linked to human presence and the specific characteristics of the geomorphosite.

\section{Zusammenfassung: Evaluation von geomorphologi- schen Geotopen, die fïr das Sportklettern genutzt werden. Das Beispiel von Monteleone Rocca Doria (Sardinien, Italien)}

Im Rahmen der Evaluation von geomorphologischen Geotopen und ihrer touristischen Nutzung konzentriert sich ein neues Forschungsfeld auf Gebiete, die für Freiluftsportarten wie das Sportklettern genutzt werden. Letzteres ist eng mit den geologischen und geomorphologischen Charakteristika eines solchen Gebiets verbunden, insbesondere mit den für das Klettern geeigneten Felswänden. Es wurde eine Methodologie erarbeitet, die auf einer spezifischen Überwachung der geomorphologischen Gefahren, der Felsbeschaffenheit des touristischen Potentials sowie der Verletzlichkeit basiert. Die Methodologie wurde anschliessend in einigen bedeutenden italienischen Klettergebieten getestet. Das Gebiet von Monteleone Rocca Doria (Sardinien, Italien) dient hier als emblematisches Beispiel - ein Gebiet von wissenschaftlichem, ästhetischem und kulturellem Wert, das kürzlich für das Klettern ausgerüstet wurde. Ziel des vorliegenden Beitrages ist es, eine Nutzung des Gebiets aufzuzeigen, die sowohl die Sicherheit der Benutzer, den Schutz des geomorphologischen Geotops, als auch eine koordinierte Nutzung der ganzen Region, in der sich das Gebiet befindet, ermöglicht. Die touristische Eignung des geomorphologischen Geotops, die potentiellen Risikofaktoren durch geomorphologische Gefahren wie auch die Auswirkungen der Präsenz des Menschen und die spezifischen Charakteristika des Gebiets werden evaluiert.

\section{Résumé: Evaluation de géomorphosites utilisés pour l'escalade sportive. L'exemple de Monteleone Rocea Doria (Sardaigne, Italie)}

Dans le cadre des recherches sur l'évaluation des géomorphosites et leur usage touristique, un nouveau domaine de recherche concerne les sites utilisés pour les activités de plein air comme l'escalade sportive. Cette activité est en effet étroitement dépendante des caractéristiques géologiques et géomorphologiques des sites. Une méthodologie basée sur l'étude du danger d'origine géomorphologique, de la qualité de la roche, du potentiel touristique et de la vulnérabilité a ensuite été testée sur différents sites d'escalade italiens. Le site de Monteleone Rocca Doria (Sardaigne, Italie) est présenté comme exemple emblématique. Il s'agit d'un site d'importance scientifique, esthétique et 
culturelle, qui a récemment été équipé pour l'escalade. L'objectif de cet article est de proposer une utilisation du site garantissant autant la sécurité des usagers que la protection du géomorphosite, ainsi qu'un usage coordonné de l'ensemble de la zone dans laquelle s'inscrit la paroi d'escalade. La vocation touristique du géomorphosite, les facteurs potentiels de risque liés aux aléas géomorphologiques ainsi que les impacts dus à la présence humaine et les caractéristiques spécifiques du site ont été évalués.

Prof. Dr. Valeria Panizza, Institute of Geography, University of Sassari, Piazza Conte di Moriana, 8, I-07100 Sassari, Italy.

e-mail: valeria@uniss.it

Dr. Marco Mennella, Geology and Mineralogy Institute, University of Sassari, Corso Angioj, I-07100 Sassari, Italy.

e-mail: marco.mennella@tiscali.it

Manuskripteingang/received/manuscrit entré le 22.3.2007

Annahme zum Druck/accepted for publication/accepté pour l'impression: 3.10 .2007 